Thomas Henry Huxley, a leading proponent of Darwin's theory of evolution. Young George was favourably inclined to Huxley's views and had spirited discussions on the subject with his father.

George M. Dawson was a geologist, author, teacher, civil servant, anthropologist, palaeontologist, surveyor, mapper, photographer, artist and poet. A number of his photographs, sketches, and poems are interspersed throughout this book. Although he was named geologist and naturalist to the North American Boundary Commission in 1873-74, his skills in natural history were weak (Jenkins fails to share this fact). In northern Montana, just south of the $49^{\text {th }}$ parallel, he observed the last great herds of Bison and came across skeletons resulting from the slaughter of 21 plains Indians. Dawson named a number of geographic features in the Queen Charlotte Islands and the interior of British Columbia that are still in use today. He suffered the pain of unrequited love and remained a bachelor until his premature death from an acute chest infection at age 51 .

I agree with Jenkins (page 2), that Dawson was "a writer ... of endearing wit, evocative description, and illuminating fact." He described an Orkneyman in the employ of the Hudson's Bay Company as "an amiable Hudson Bay Fossil." He used the term "liquid excisable articles" to describe spirituous liquors.

This book has not achieved its full potential. I spotted the following misspellings and factual errors, presumably made by Dawson and not by Jenkins: alumni (when alumnus was indicated), latitude (when longitude was meant), astrological (astronomical), peninsular (peninsula), tit bits (tid bits), $100^{\text {th }}$ meridian $\left(110^{\text {th }}\right.$ meridian), prairie chickens (Sharp-tailed Grouse), Dr Helckin (Dr Helmcken), F.R.C. (F.R.S.), silver load (silver lode), and Bearing Sea (Bering Sea). There is

\section{The Wolf Totem}

By Jiang Rong. 2004. Changjiang Literary Art Press. Pages: 478; \$18. Yuan RMB.

[Editors note: The Penguin Group, under the British Pearson Education Company, bought the copyright and will publish an English version in 2007. This researchedbased novel has topped China's bestseller list for 16 straight months, selling about 1 million copies.]

The Chinese press has not published a significant book in many years. However, in April of 2004, the Changjiang Literary Art Press of China published the novel-style book The Wolf Totem, which was written by an author bearing the pseudonym Jiang Rong. The response from the media and the public was rapid and it became a best seller.

The book is composed of various relatively independent stories. The narration of each story is full of craftsmanship, firing one's imagination and stirring one's emotion. The novel-style book is a marvellous, little doubt that a University press would have encouraged Jenkins to insert the correct spellings in square brackets, as well as to include an index, explanatory footnotes (e.g., to add the initials and explain the importance of Dr. W. F. Tolmie, surgeon to the Hudson's Bay Company), and a bibliography. The latter would have included Life and Letters of George Mercer Dawson, 1849-1901, by Lois Winslow-Spragge, Dawson's niece, and would have listed the available photocopies of Dawson's detailed field notebooks which Jenkins seems to have ignored. Similarly, we are not told that Sapper Duckworth was Dawson's collector and taxidermist in 1873-74, that white cranes were Whooping Cranes, that the blue jay was probably a Steller's Jay, that the hummingbird nest was likely that of a Rufous Hummingbird, and that the name of the destructive but now extinct Rocky Mountain Locust has since changed from Caloptenus spretus to Melanoplus spretus.

A longer introductory essay or a postscript could have allowed a more complete assessment of Dawson's great achievements which Dawson modestly did not mention. We learn, for example, that Dawson received an honorary doctorate from the University of Toronto, but those from Princeton, Queen's and McGill, and other high honors, are not mentioned.

In spite of the shortcomings mentioned, Dawson's skills make this book a treasure, a lasting contribution to Canadian history. I recommend it highly to the general public. It deserves a place in every university and high school library.

C. Stuart Houston

863 University Drive, Saskatoon, Saskatchewan S7N 0J8 Canada

unprecedented way to present many stories of the enigmatic animal of the steppe, the wolf. The stories are not only charming in their sense of humanity, but also colourful and valuable in their understanding of the ecological role played by the Wolf. After reading the book, readers will be enlightened, moved and even shocked by the vivid ecological ethics conveyed in the book. The publication of the book can be regarded as an important event for both literature and ecologists.

From the viewpoint of ecology, a steppe may be regarded as a special type of ecosystem seemingly simple in structure and function, but essentially diverse, complicated and unpredictable. From the perspective of humanity, a boundless steppe may be mysterious, thought inspiring and soul stirring, sometimes touching and sometimes plaintive. In the cultural evolutionary history of the world, the acted steppe as an endless wellspring of artistic creation and a boundless field for sci- 
entific exploration. The anecdotes and the legends, the music and the paintings related to the steppe are uncountable; the study cases concerning the steppe ecosystem are also voluminous.

Turning aside from the fascinating visions and thrilling scenes the author describes in each story, and turning aside from the totem of wolf at the level of politics and humanities the author elucidates in his narration, the book is of important ecological values. The descriptions of the behaviours of the Wolf populations in teamwork, reconnaissance, ambuscade, and surprise attack, and the unusual wisdom exhibited in making use of weather and topography, as well as the discussions on the relationships among the populations of Wolf and human, sheep and grass can be regarded as very vivid and enlightening material. However, it is a pity that in an otherwise valuable book that the author does not give the basic scientific and quantitative relationships among the component populations of the ecosystem. This may be beyond the scope of this style of book.

All these mysterious stories took place in the steppes of northern China during a special period more than nearly 40 years ago when the author and his classmates as urban school graduates laboured in the countryside in response to the political call of Chairman Mao. At that time, the vast area of steppe of northern China had plenty of water and lush grass, creating a beautiful landscape. But afterward, due to overgrazing and farming, the steppe ecosystem degenerated rapidly.

China is the second largest country in the world in terms of the steppe area. However, due to the increase in large scale agriculture in the half century from $1949,5 \%$ of the natural steppe area was turned into farmland [This constituted one fifth of the total farmland of China]. This has resulted in more than a quarter of Chinese land being threatened by desertification. More than $90 \%$ of the steppe has been degenerated and such degeneration is expanding at the rate of 2 million $\mathrm{km}^{2} / \mathrm{yr}$. Since steppe restoration is becoming harder and harder in China, all the stories about the steppe in the past are becoming almost unrepeatable. This further implicates the extreme rarity and the important value of the material in this book.

Ecosystems with multiple-trophic levels are complicated and maintaining the stability is critical. In a typical steppe ecosystem with three trophic levels: carnivore, herbivore and grass, the carnivore usually plays a top-down effect on the community structure, and by this means grass tends to be protected to some extent. The theory of trophic cascade and HSS hypothesis is useful in explaining, "Why the terrestrial world tended to be green." McLaren and Peterson (1994) used tree ring data to show how a top-down effect of Wolf populations on Isle Royale reduced Moose abundance resulting in an increase in the growth increment of forage trees. The Wolf Totem shows that in the northern China about one century ago, harmonious relationships among the component populations of the ecosystem did exist, and the relative stability of the pasture was naturally maintained. This supports the rationality of the theories as mentioned above. However, considering the present situations of the rapidly degenerated steppe ecosystem in northern China, the above-mentioned theories encounter limitations, because they do not deal with how and why "the terrestrial world turned from green to yellow or black" due to over-use and human disturbance. If a disturbance dimension was added to the theories and each dimension were given a threshold, the theories would become more general, compatible and extendable.

The Mongolians, the native people in the northern China, fully understood the natural laws of mutual restriction and dynamic balance among the population of wolf, sheep and grass in the steppe ecosystem in their long history dealing with nature, and knew how to efficiently live within these laws. They never killed all of the Wolves, never bred the sheep excessively and never over-grazed the pasture. The accumulation of such ecological wisdom imitating nature, acclimating nature and making use of nature, moulded the Mongolian nationality. On the contrary, by disobeying the laws of nature, they have unavoidably learnt a painful lesson about the degeneration of the steppe.

When human or social-economic dimensions are added into a natural ecosystem, it would become a social-economic-natural-complex-ecosystem (SENCE). The present steppe ecosystem in northern China is such a SENCE. Keeping such a SENCE developing in a harmonious way is a new challenge to China with ever-increasing population. The classical Chinese philosophy, such as The Doctrine of the Mean, emphasizes human's active roles such as participation, promotion, coordination and cultivation rather than domination, so as to reach harmony between human and nature. Combining the classical Chinese philosophy with the modern ecological theories and using the actual experiences and lessons for references, steppelike SENCE would be managed more effectively. The Wolf Totem with its stories of a rural youth living among Inner Mongolian nomads and wolves tells of this grassland environment and nomadic culture. Reading The Wolf Totem will bring the reader a better understanding of the ecology of the Chinese-Mongolian steppe.

\section{Literature Cited}

McLaren, B. E., and R. O. Peterson. 1994. Wolves, moose and tree rings on Isle Royale. Science 266: 1555-1558.

\section{Li DEZHI ${ }^{1}$, QIN AILI ${ }^{2}$, AND QIN HONG ${ }^{3}$}

${ }^{1}$ Lab of Urbanization and Ecological Restoration of Shanghai; National Field Observation and Research Station in Tiantong Forest Ecosystem of Zhejiang; Department of Environmental Science, East China Normal University, 3663, Zhongshan Rd (N). Shanghai, China 200062)

${ }^{2}$ Jilin Forestry Staff School, Jilin, China

${ }^{3}$ Zhejiang University, Hangzhou, China 


\section{Erratum The Canadian Field-Naturalist 126(4)}

In response to the review of Contributions to the History of Herpetology. CFN 126(3): 344-345, the book's editor Kraig Adler pointed out (personal communication to FRC 12 May 2013): "Only one small correction. Mrs. Martof used a kitchen knife, not a gun. She told the police she slipped while cutting some pizza. But Bernie was stabbed up under his rib cage several times!"

\section{Erratum The Canadian Field-Naturalist}

It has come to our attention that sections of many of the book reviews by Li Dezhi and Qin Aili were copied from sources without attribution. The journal and the authors apologize for this oversight. 